\title{
Security Analysis of Banking Industry in Bangladesh
}

\author{
Omar Faruque ${ }^{*}$, Md. Rafiul Islam ${ }^{2}$ \\ ${ }^{1}$ Assistant Professor, Department of Accounting and Information Systems, Begum Rokeya University, Rangpur, BANGLADESH \\ ${ }^{2}$ Lecturer, Department of Business Administration, Pundra University of Science \& Technology, Bogura, BANGLADESH \\ *E-mail for correspondence: faruque1712@gmail.com
}

https://doi.org/10.18034/abr.v8i1.4

\begin{abstract}
The paper aims to know what about the procedure of analysis for determining the investment decision in the stock market on by studying different method of the securities analysis. This study is an attempt to highlight the different securities analysis methods for making the rational decision about the investment in the stock market. The security analyses show the result of fundamental and technical tools of analyses. The study reveals that Uttara bank Ltd. among the selected three banks is doing well and one can go for making an investment decision. The report mainly focuses on the decision criteria to purchase and to sell the securities and when to do so.
\end{abstract}

Key words: Security analysis, stock market, banking sector, Bangladesh

\section{INTRODUCTION}

The analysis of tradable financial instruments is called security analysis. It deals with the finding of proper valuation of individual securities (i.e. stocks and bonds). It is a method of evaluating security. The security analysis entails attempting to measure the security's intrinsic value. It is done through by the examining of related economic, financial and other qualitative and quantitative factors. The fundamental analysts of economics attempt to study everything that can affect the security's value including macroeconomic factors and company-specific factors. The macroeconomic factors are the overall economy, and industry conditions and the companyspecific factors are the financial condition and management. The terminated goal of performing this fundamental analysis is to produce a value that an investor can compare with the security's current price. The aim of figuring out what the sort of position is to take with that security. It may be underpriced = buy, overpriced $=$ sell or short. The method of security analysis is considered as the opposite of the technical analysis.

Al Arafah Islami Bank Ltd was established (registered) as a public limited company on 18 June 1995 . The objective of this bank is to achieve success in life here \& hereafter followed by the way directed by Islam. Its inaugural ceremony took place on 27 September 1995. On December 31, 2015, the authorized capital of the bank was Tk. 15000.00 million and the paid-up capital was Tk. 9469.58 million.
It has made a positive contribution towards the socioeconomic development of the country with 155 branches of which 23 is AD throughout the country.

The Uttara Bank Limited was incorporated as a banking company on 21.8.1983 and obtained business commencement certificate on 21.8.1983. The bank floated its shares in the year 1984. It has 233 branches all over the Bangladesh which is carries out all its activities. The Bank is listed in the Dhaka Stock Exchange and the Chittagong Stock Exchange Ltd as a listed company for trading of its shares.

The One Bank was incorporated as a banking company in 12 May, 1999 and obtained the certificate of business commencement in 12 May 1999. The One Bank is enlisted under the both Dhaka and Chittagong Stock Exchange Limited for trading its shares. The Bank has almost 95 branches all over the country.

\section{Objectives of the Study}

The main objective of the study is to analyze the Security of banking industry of Bangladesh. The other objectives are -

- To know the market price status of the selected banks.

- To know the yardstick of decision making for investment in stock market.

- To evaluate the performance of the stock experiencing in the market of the Banking industry.

- To suggest some recommendations. 


\section{MetHodology}

Secondary sources of data have been used to conduct the study, the. To serve the objectives of the study three banks of Bangladesh have been selected as the sample of the banking industry and the annual reports (5-year data: 2013-17) of the selected banks have been studied. To analyze the topic different fundamental and technical methods (Ratio analyses, Simple moving average calculation, Relative Strength Index, etc.) of analyses have been used. To present the data tabular form and graphical method have been utilized.

\section{LITERATURE REVIEW}

According to Rudra and Jaydev (2009), a sensitivity of bank stocks to Risk management has been analyzed. The general inference from their analysis is that the returns of Indian bank stocks appear to be sensitive to the risk management capability of banks. They suggested the banks focus on risk management techniques to enhance their shareholder value.

Sinha (2013) studied a comparison was made between Risk and Return of Banking sector equity with nonbanking sector equity, and she concluded that investing in Banking stocks include high risk because this sector is highly affected by market risk factors like a global recession. She suggested the investors hold the shares for a long-term to earn good returns in the banking sector.

Limbore and Baban (2014) studied that deals with the comparative analysis of advances and non-performing assets in public and private sector banks in the light of mounting competitive scenario in the banking sector. It has been observed that there is an increase in advances over the period of the study.

The Indian banking system is still dominated by the public sector banks, and the issues of performance and efficiency have emerged to be the touchstone for the success of such banks. Vegesna and Dash (2014) stated that there is a need to develop a comprehensive framework for measuring their efficiency in transforming their resources for better performance. Such performance benchmarking has become extremely relevant to their success. This study focuses on the technical efficiency of banks in India using Data Envelopment Analysis (Goncharuk, 2013), to identify critical factors affecting the efficiency of banks.

Saleheen et al. (2014) showed the findings based on primary data are giving an opportunity for the industry practitioners to review their operations' practice and suggested the intricacies to improve the operational efficiencies in the IT platform to upgrade the E-commerce facilities.

Dumontier and Raffournier (2002), studied the classifies the European literature into three groups: studies of the market reaction to newly released accounting information; studies of the long-term association between stock returns and accounting numbers; studies devoted to the use of accounting data by investors and to the impact of market pressure on accounting choices.

\section{DISCUSSION AND FINDINGS}

\section{The Fundamental Analyses}

Company analysis is the main fundamental analytical tools. In the company analysis, we can evaluate different types of ratios for the decision consideration, and some of these are given below-

Calculation of Price Earnings Ratio:

Price Earnings Ratio $=\frac{\text { Market price per Share }}{E P S}$ Times

Table 1: Calculation of Price Earnings Ratio

\begin{tabular}{|c|c|c|c|}
\hline \multicolumn{4}{|c|}{ Price Earnings Ratio } \\
\hline & $\begin{array}{c}\text { Al Arafah } \\
\text { Bank Ltd. }\end{array}$ & $\begin{array}{c}\text { One } \\
\text { Bank Ltd. }\end{array}$ & $\begin{array}{c}\text { Uttara } \\
\text { Bank Ltd. }\end{array}$ \\
\hline 2017 & 7.64 & 8.03 & 9.07 \\
\hline 2016 & 5.18 & 5.89 & 6.45 \\
\hline 2015 & 6.53 & 4.69 & 6.04 \\
\hline 2014 & 6.77 & 3.95 & 7.46 \\
\hline 2013 & 7.76 & 5.58 & 9.48 \\
\hline Average & 6.78 & 5.63 & 7.70 \\
\hline
\end{tabular}

Under the company analysis with the ratios if we consider the Price Earnings Ratio of the three banks as taken with the consideration of 5 consecutive years, i.e., from 2013 to 2017, we get different percentage at different years and the average of the 5 years is 6.78 times for the Al Arafah Islami Bank, 5.63 times for the one Bank Limited and 7.70 times for the Uttara Bank Limited. So, here the ratio of the Uttara Bank Limited is higher than others and this bank will be the selected bank for the investment.

Calculation of Return on Asset (ROA) ratio:

$\mathrm{ROA}=\frac{E A T}{\text { TotalAssets }}$

Table 2: Calculation of Return on Asset ratio

\begin{tabular}{|c|c|c|c|}
\hline \multicolumn{5}{|c|}{ ROA } \\
\hline & $\begin{array}{c}\text { Al Arafah } \\
\text { Bank Ltd. (\%) }\end{array}$ & $\begin{array}{c}\text { One Bank } \\
\text { Ltd. (\%) }\end{array}$ & $\begin{array}{c}\text { Uttara Bank } \\
\text { Ltd. (\%) }\end{array}$ \\
\hline 2017 & 0.99 & 1.05 & 0.87 \\
\hline 2016 & 1.23 & 1.20 & 0.94 \\
\hline 2015 & 1.08 & 1.39 & 0.99 \\
\hline 2014 & 1.10 & 1.87 & 0.99 \\
\hline 2013 & 1.31 & 1.43 & 0.99 \\
\hline Average & 1.14 & 1.39 & 0.96 \\
\hline
\end{tabular}

When we go for the consideration of the ROA ratio of the three banks, we can see that the ratio is $1.14 \%$ for the Al Arafah Islami Bank, $1.39 \%$ for the one Bank Limited And .96\% for the Uttara Bank Limited. So here also the One Bank Limited has the higher ratio and could be the sector for investment.

Calculation of Return on Equity (ROE) ratio:

$\mathrm{ROE}=\frac{E A T}{\text { ShareholdersEquity }}$ 
Table 3: Calculation of Return on Equity ratio

\begin{tabular}{|c|c|c|c|}
\hline \multicolumn{4}{|c|}{ ROE } \\
\hline & $\begin{array}{c}\text { Al Arafah Bank } \\
\text { Ltd. (\%) }\end{array}$ & $\begin{array}{c}\text { One Bank } \\
\text { Ltd. (\%) }\end{array}$ & $\begin{array}{c}\text { Uttara Bank } \\
\text { Ltd. }(\%)\end{array}$ \\
\hline 2017 & 14.07 & 9.62 & 11.20 \\
\hline 2016 & 15.70 & 10.07 & 11.47 \\
\hline 2015 & 12.82 & 11.32 & 11.42 \\
\hline 2014 & 12.80 & 12.88 & 11.41 \\
\hline 2013 & 14.15 & 14.08 & 12.27 \\
\hline Average & 13.91 & 11.59 & 11.55 \\
\hline
\end{tabular}

When we go for the consideration of the ROE ratio of the three banks, we can see that the ratio is $13.91 \%$ for the $\mathrm{Al}$ Arafah Islami Bank, $11.59 \%$ for the one Bank Limited And $11.55 \%$ for the Uttara Bank Limited. So here the Al Arafah Islami Bank has the higher ratio and it would be better sector for the investment.

\section{Technical analysis}

Table 4: Simple Moving Average calculation of company's share value

\begin{tabular}{|c|c|c|c|c|c|c|c|c|c|}
\hline \multicolumn{10}{|c|}{ Simple Moving Average } \\
\hline Day & Al Arafah Bank Limited & \multicolumn{2}{c|}{ One Bank Limited } & \multicolumn{2}{|c|}{ Uttara Bank Limited } \\
\hline & $\begin{array}{c}\text { Closing } \\
\text { price (Tk) }\end{array}$ & $\begin{array}{c}\text { Botal of } \\
5 \text { days }\end{array}$ & $\begin{array}{c}\text { Days } \\
\text { MA }\end{array}$ & $\begin{array}{c}\text { Closing } \\
\text { price (Tk) }\end{array}$ & $\begin{array}{c}\text { Total of } \\
5 \text { days }\end{array}$ & $\begin{array}{c}5 \text { Days } \\
\text { MA }\end{array}$ & $\begin{array}{c}\text { Closing } \\
\text { price (Tk) }\end{array}$ & $\begin{array}{c}\text { Total of } \\
5 \text { days }\end{array}$ & $\begin{array}{c}\text { Days } \\
\text { MA }\end{array}$ \\
\hline 1 & 18.40 & - & - & 18.00 & - & - & 33.30 & - & - \\
\hline 2 & 18.70 & - & - & 17.60 & - & - & 33.90 & - & - \\
\hline 3 & 19.20 & - & - & 18.00 & - & - & 33.60 & - & - \\
\hline 4 & 19.20 & - & - & 18.20 & - & - & 33.80 & - & - \\
\hline 5 & 18.70 & 94.20 & 18.84 & 24.20 & 96.00 & 19.20 & 33.80 & 168.40 & 33.68 \\
\hline 6 & 19.80 & 95.60 & 19.12 & 18.60 & 96.60 & 19.32 & 34.10 & 169.20 & 33.84 \\
\hline 7 & 20.00 & 96.90 & 19.38 & 18.80 & 97.80 & 19.56 & 34.20 & 169.50 & 33.90 \\
\hline 8 & 19.00 & 96.70 & 19.34 & 20.80 & 100.60 & 20.12 & 34.30 & 170.20 & 34.04 \\
\hline 9 & 18.90 & 96.40 & 19.28 & 21.80 & 104.20 & 20.84 & 34.50 & 170.90 & 34.18 \\
\hline 10 & 19.20 & 96.90 & 19.38 & 22.00 & 102.00 & 20.40 & 34.60 & 171.70 & 34.34 \\
\hline 11 & 19.70 & 96.80 & 19.36 & 22.20 & 105.60 & 21.12 & 35.20 & 172.80 & 34.56 \\
\hline 12 & 19.10 & 95.90 & 19.18 & 22.20 & 109.00 & 21.80 & 35.30 & 173.90 & 34.78 \\
\hline
\end{tabular}

Whenever we go for the simple moving average consideration, we see that the average of Uttara bank Ltd is better than others since face value of each company's share is equal i.e., Tk. 10 .

\section{Calculation of Relative Strength Index (RSI)}

Traditionally the Relative Strength Index is considered overbought when above 70 and oversold when below 30 .

Table 5: Calculation of Relative Strength Index

\begin{tabular}{|c|c|c|c|c|c|c|c|c|c|}
\hline \multicolumn{10}{|c|}{ Relative Strength Index (RSI) } \\
\hline Day & Al Arafah Bank Limited & \multicolumn{2}{c|}{ One Bank Limited } & \multicolumn{3}{c|}{ Uttara Bank Limited } \\
\hline & $\begin{array}{c}\text { Closing } \\
\text { price (Tk) }\end{array}$ & Gain & Loss & $\begin{array}{c}\text { Closing } \\
\text { price (Tk) }\end{array}$ & Gain & Loss & $\begin{array}{c}\text { Closing } \\
\text { price (Tk) }\end{array}$ & Gain & Loss \\
\hline 1 & 18.4 & - & - & 18 & - & - & 33.3 & - & - \\
\hline 2 & 18.7 & 0.3 & - & 17.6 & - & 0.4 & 33.9 & 0.6 & - \\
\hline 3 & 19.2 & 0.5 & - & 18 & 0.4 & - & 33.6 & - & 0.3 \\
\hline 4 & 19.2 & - & - & 18.2 & 0.2 & - & 33.8 & 0.2 & - \\
\hline 5 & 18.7 & - & 0.5 & 24.2 & 6 & - & 33.8 & - & - \\
\hline 6 & 19.8 & 1.1 & - & 18.6 & - & 5.6 & 34.1 & 0.3 & - \\
\hline 7 & 20 & 0.2 & - & 18.8 & 0.2 & - & 34.2 & 0.1 & - \\
\hline 8 & 19 & - & 1 & 20.8 & 2 & - & 34.3 & 0.2 & - \\
\hline 9 & 18.9 & - & 0.1 & 21.8 & 1 & - & 34.5 & 0.2 & - \\
\hline 10 & 19.2 & 0.3 & - & 22 & 0.2 & - & 34.6 & 0.1 & - \\
\hline 11 & 19.7 & 0.5 & - & 22.2 & 0.2 & - & 35.2 & 0.6 & - \\
\hline 12 & 19.1 & - & 0.6 & 22.2 & - & - & 35.3 & 0.1 & - \\
\hline & Total & 2.9 & 2.2 & Total & 10.2 & 6 & Total & 2.4 & 0.3 \\
\hline & $\begin{array}{l}11 \text { Days } \\
\text { Average }\end{array}$ & 0.26364 & 0.2 & $\begin{array}{c}11 \text { Days } \\
\text { Average }\end{array}$ & 0.9273 & 0.5455 & $\begin{array}{c}\text { Average } \\
\text { Averas }\end{array}$ & 0.2182 & 0.0273 \\
\hline
\end{tabular}

Al Arafah Islami Bank Ltd

$\mathrm{RS}=\frac{\text { Average gain per day }}{\text { Average loss per day }}$

RSI $=100-\left(\frac{100}{1+R S}\right)$

So, $R S=\frac{0.26}{0.2}$

$=1.3$

RSI $=100-\left(\frac{100}{1+1.3}\right)=100-43.48,=56.52$

Here the RSI value above 70 indicates the overbought condition and values below 30 are considered to denote oversold condition for the Al Arafah Islami Bank Ltd. and should hold up the security of the bank.

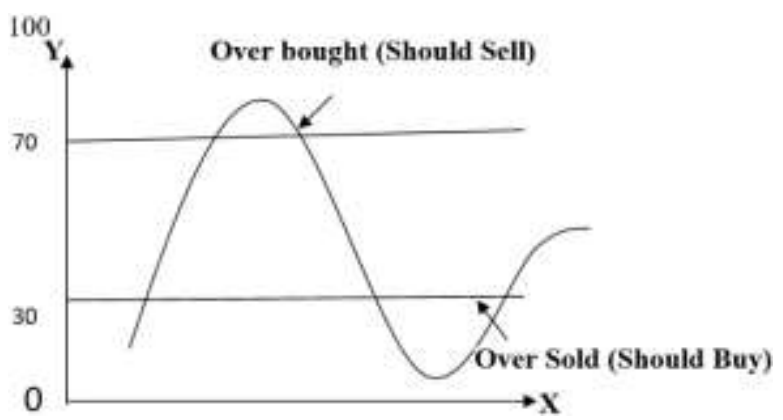

One Bank Ltd

$\mathrm{RS}=\frac{0.93}{0.55}$

$=1.69$

RSI $=100-\left(\frac{100}{1+1.69}\right)=100-37.17,=62.83$

Here the RSI value 62.83 indicates the perfect value is in exercising in the security market for the One Bank Ltd. and should hold up the security of the bank.

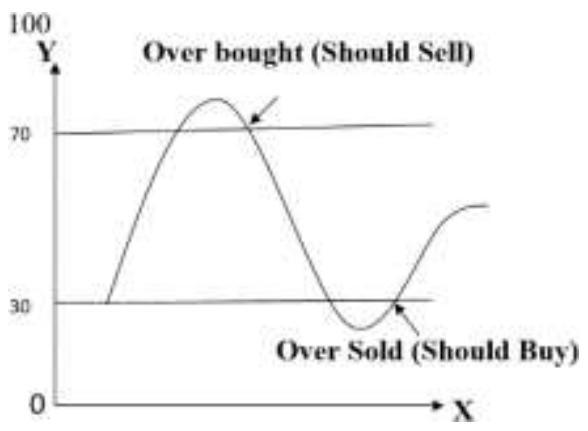

Uttara Bank Ltd

$\mathrm{RS}=\frac{0.22}{0.03}$

$=7.33$

RSI $=100-\left(\frac{100}{1+7.33}\right)=100-12,=88$ 
Here the RSI value is 88 which indicate the overbought condition for the Uttara Bank Ltd. and should go for selling the security in the capital market because the market will bounce back quickly.

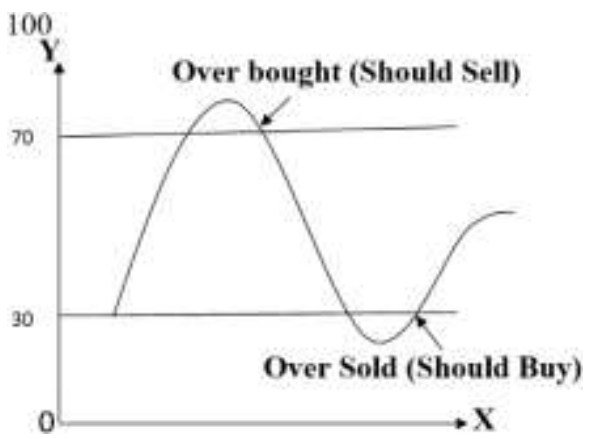

The overall decision for the investment in securities is that on the basis of the present study we can see that the fluctuation of the securities prices of the Uttara Bank Limited is very limited or may be termed as the ripple and the management body is efficient enough considering the banking operation. So the investment in Uttara bank limited will be the lucrative one for the long run.

\section{RECOMMENDATIONS}

Considering the changes in the business era and competitive situation in case of the banking industry and by our analysis with the gap and weak point in case of market experience, we can go for recommendation as the way-

- Based on the fundamental analysis result go for the technical analysis because technical analysis is based on short-term period.

- Before going for the investment decision, one should consider the systematic and unsystematic risk.

- Investment decision should be based on the intrinsic value of the share or the stock.

- One should ensure that all the analysis methods have been conducted with the highly efficient person.

- Neither fundamental analysis nor technical analysis is useful in outperforming the markets.

\section{CONCLUSION}

The banking sector in Bangladesh is playing a vital role in the economic development as a financial intermediary. So the banking sector of a country is blood for the development. Now the interest rate, exchange rate, Inflation rate of the Bangladesh is whatever that could be the matter for the government to think over the fact primarily and with the changes of that types of the indicator of the economy the financial activities of the banking sector will be hampered but thus the activities of the banking sector still go for continuing. Economists such as Burton Malkiel suggest that neither fundamental analysis nor technical analysis is useful in outperforming the markets. There are many types of the business sector s in Bangladesh and they operate their activities for the profit motive is primarily more vulnerable than the banking sector. So the investment in the banking sector is compatibly more favorable than the other sectors in Bangladesh.

\section{REFERENCES}

Ahmed AA. 2009. The Effect of Timeliness Regulation of Corporate Financial Reporting: Evidence from Banking Sector of Bangladesh Accounting and Management Information Systems, 8, 216 - 235.

Al Arafah Islami Bank Limited, Annual Report 2017

Dey MM and Ahmed AA. 2009. Bank Loan Officers' Perceptions of Corporate Financial Disclosure in the Banking Sector of Bangladesh: An Empirical Analysis Research Paper, 1-8.

Dumontier, P., and B. Raffournier: Accounting and capital markets: A Survey of the European evidence, The European Accounting Review, 2002.

Goncharuk, A. G. (2013), "About the Influence of High Gas Price on an Efficiency", Journal of Applied Management and Investments, Vol. 2 No. 1, pp. 58-67.

Kevin, S., Portfolio Management, $2^{\text {nd }}$ Edition, https:/ / slideblast.com/portfolio-management-s-kevin2nd-edition-solution-pdf_59754cc11723dda3a7ec3564.html

Khan h. Jahangir, "Environmental and individual determinants of entrepreneurial growth" (Journal of Business administration vol.34, no.3 \& 4 July \& October, 2008)

Limbore N. V and Baban, M. (2014) "A study of banking sector in India and overview of performance of Indian banks with reference to net interest margin and market capitalization of banks" Source: Review of Research [2249-894X]. | vol:3 | iss:6

One Bank Limited, Annual Report -2017

Pascal Dumontier \& Bernard Raffournier (2002) Accounting and capital markets: a survey of the European evidence, European Accounting Review, 11:1, 119-151, DOI: $10.1080 / 09638180220124761$

Rudra, S. and Jayadev, M. (2009). Is Bank Stocks Sensitive to Risk Management?

Saleheen, F., Miraz, M.H. and Ramli, R. (2014), "IT Operations in Retail Banking: A Case Study", Journal of Applied Management and Investments, Vol. 3 No. 4, pp. 245-250.

Sinha, R. (2013). "An analysis of Risk and Return in equity investment in banking sector.

Uttara Bank Limited, Annual Report -2017

Vegesna, S. and Dash, M. (2014), "Efficiency of Public and Private Sector Banks in India", Journal of Applied Management and Investments, Vol. 3 No. 3, pp. 183-187.

\section{Webpages:}

https:/ /issuu.com/lawjuris/docs/al-arafah_islami_bank_ltd.

https://www.coursehero.com/file/p1gcgmp/Page-8-

Directors-consists-of-15-members- The-bank-is-headedby-the-Managing/

https://www.investopedia.com/terms/f/fundamentalanalysis.asp $--0--$

Online Archive: https://abc.us.org/ojs/index.php/abr/issue/archive 